\title{
Características clínicas y de laboratorio en pacientes cirróticos asociada con desnutrición moderada o severa
}

\section{Clinical and laboratory characteristics of cirrhotic patients associated with moderate and severe malnutrition}

\begin{abstract}
Context and objective: Protein-energy malnutrition is described Context and objective: Protein-energy malnutrition is described in $25-100 \%$ of patients with cirrhosis. The aim of this study was to evaluate the nutritional status of cirrhotic patients, to identify clinical and laboratory variables associated with moderate to severe malnutrition and to correlate them with cirrhosis prognostic factors (Child-Pugh Classification). Design and setting: This cross-sectional study evaluated cirrhotic individuals admitted to University Hospital from December 2011 to August 2012. Methods: Nutritional status was evaluated by Subjective Global Assessment (SGA), total lymphocyte count and serum albumin. Bivariate analysis was used to identify variables associated with Child $C$ and with moderate to severe malnutrition in different nutritional classifications. Results: Sixty-seven patients were included (mean age $54.4 \pm 11.7$ years; $74.6 \%$ men). The mean MELD score was $14.5 \pm 6.5$, and almost $30 \%$ of the individuals were classified as Child C. With respect to nutritional status, $20.9 \%$ showed severe malnutrition by SGA, $14.9 \%$ malnutrition by total lymphocyte count, and $40.3 \%$ by albumin levels. In all methods employed, moderate to severe malnutrition was correlated with Child classification grade $C$. The rate of moderate to severe malnutrition by SGA was lower than that evidenced by laboratory methods. Nevertheless, SGA indicated a greater proportion of Child C patients with moderate to severe malnutrition. Conclusion: Due to the high prevalence of malnutrition and its correlation to the severity of cirrhosis, the nutritional evaluation of cirrhotic patients is an essential step that can be performed through simple methods in routine hospital care. Key words: Liver cirrhosis, lymphocyte count, malnutrition, nutrition assessment, serum albumin.
\end{abstract}

Samantha Thifani Alrutz Barcelos (1) Esther Buzaglo Dantas-Corrêa (1) Maria Luiza Aires Alencar (2) Leonardo de Lucca Schiavon (1) Janaina Luz Narciso-Schiavon (1)

(1) Núcleo de Estudos em Gastroenterologia e Hepatologia (NEGH), Universidade Federal de Santa Catarina (UFSC), Florianópolis, Santa Catarina, Brazil. (2) Núcleo de Pesquisa de Nutrição em Produção de Refeições (NUPPRE), Hospital Universitário Polydoro Ernani de São Thiago, Universidade Federal de Santa Catarina (UFSC), Florianópolis, Santa Catarina, Brazil.

Author correspondence: Janaína Luz Narciso-Schiavon Departamento de Clínica Médica Universidade Federal de Santa Catarina (UFSC) Hospital Universitário Polydoro Ernani de São Thiago, Rua Professora Maria Flora Pausewang, s/no, 30 andar Trindade Florianópolis (SC, Brasi CEP $88040-900$ Tel. $(+5548) 3721-9149$ E-mail: janaina.narciso@uol.com.br

Este trabajo fue recibido el 12 de Noviembre de 2013 y aceptado para ser publicado el 30 de Enero de 2014.

\section{INTRODUCTION}

Protein-energy malnutrition is frequently found in patients with advanced liver disease (1). It is described in 50 to $100 \%$ of patients with decompensated cirrhosis and in at least $25 \%$ of those with compensated cirrhosis( 2-4). Protein-energy malnutrition leads to serious consequences for the patient's general condition and clinical evolution $(3,5,6)$, Nutritional supplementation has been associated with reduced infection risk and intra-hospital mortality, as well as the improvement of liver function $(7,8)$.

Multiple factors contribute directly to the malnutrition that frequently affects patients with cirrhosis: poor food intake, regardless of the disease's stage, secondary to anorexia, early satiety, and restrictive diets (low-sodium and/ or low-protein diets); changes in the synthesis, metabolism and storage of nutrients; and poor digestion and absorption 
of nutrients or even hypermetabolism $(9,10)$. Moreover, the intensity of gastrointestinal symptoms is related to the severity of the liver disease and leads to reduced quality of life (11).

Some studies have investigated methods of nutritional evaluation in individuals with cirrhosis by means of anthropometric measurements, most commonly the triceps skinfold thickness, mid arm circumference and mid arm muscle circumference; the use of a dynamometer or the non-dominant hand grip-strength; electrical bioimpedance; indirect calorimetry; biochemical measurements such as hemoglobin, total lymphocyte count (TLC) and albumin count; and clinical nutritional evaluation, carried out by the Subjective Global Assessment of Nutritional Status (SGA) $(1,2,12-14)$.

There is no gold standard that is capable of precisely diagnosing the alterations in the nutritional state of patients with cirrhosis $(10,12)$. Several of the clinical manifestations of malnutrition are only consequences of liver dysfunction $(1,14$, $15)$, such as fluid retention, edema and ascites. These alterations are seen as major limiting factors to the predictive value of the common nutritional evaluation methods. It is difficult to apply the percentage of ideal body weight and body mass index parameters because they underestimate the severity of the malnutrition and its prevalence. However, combining distinct methodological approaches to indication (clinical, anthropometric, biochemical, dietetic, functional) reduces these restrictions $(12,16)$.

The SGA, modified by Detsky et al. (17), is a practical method to obtain a nutritional diagnosis of cirrhotic patients when access to objective nutritional evaluation data is restricted (10). This is a simple, low-cost, practical method that attains the nutritional diagnosis of the patient. It can be carried out in a few minutes at the patient's bedside and may be applied by any of several health professionals (e.g., a doctor, nutritionist, or nurse) with easy reproducibility $(10,17)$. The SGA is used in the nutritional evaluation of individuals with cirrhosis to classify their malnutrition and to predict their clinical evolution (18). Barbosa-Silva and Barros validated the SGA as a good option for the nutritional evaluation of individuals with liver disease (16). It is also one of the nutritional evaluation methods recommended by the European Society for Clinical Nutrition and Metabolism for the identification of cirrhotic patients at high risk of malnutrition (19).

Although the TLC is a widely used immunity test to evaluate immune competence, it has also been considered an effective test of nutritional status (10). Despite the controversy concerning its ability in diagnosing malnutrition $(20,21)$, this test has frequently been applied for this purpose in individuals with cirrhosis, often in association with other parameters(1, 22-26). Considered a reliable parameter in nutritional evaluation, albumin has diminished synthesis and accelerated catabolism in individuals with cirrhosis $(10,21)$. Albumin has also been used by several authors as a signal of malnutrition in this group of patients $(2,27)$.

\section{OBJECTIVE}

This study aimed to evaluate the nutritional status of cirrhotic patients by subjective (SGA) and objective (laboratory and anthropometric) parameters to identify clinical and laboratory variables associated with moderate to severe degrees of malnutrition and to correlate them with cirrhosis prognostic factors.

\section{SUBJECTS AND METHODS Patients}

This descriptive cross-sectional study included consecutive individuals with cirrhosis admitted to the University Hospital of Santa Catarina from December 2011 to August 2012. All patients were evaluated in the first three days of hospitalization. Patients with congestive heart failure, chronic pancreatitis or human immunodeficiency virus (HIV) were excluded. Those with more than one hospitalization for the same purpose and those who presented hepatic encephalopathy in stage III or IV were also excluded.

The study protocol conformed to the ethical guidelines of the 1975 Helsinki Declaration and was approved by our institutional review board under number 2443/11. Written informed consent was obtained from all subjects before study enrollment.

\section{Methods}

Clinical, laboratory and histological findings were collected from physical examination, interviews and medical records. The following clinical and demographic characteristics were recorded: age (years); gender; race; cirrhosis decompensation at the moment of hospitalization as a result of upper digestive bleeding, hepatic encephalopathy, ascites, or spontaneous bacterial peritonitis; and the presence of comorbidities (pneumonia) or bleeding (gingivorrhagia or ecchymosis). The etiology of the cirrhosis was defined by laboratory, serological and molecular biology tests. HBsAg-positive individuals were considered carriers of hepatitis B virus, and those who were HCV-RNA positive were considered carriers of hepatitis $C$ virus. Alcoholism was defined as the intake of 60 grams of ethanol per day for both women and men (28). The severity of the liver disease was evaluated by the Child-Pugh classification at the same time as the nutritional evaluation (29), and it was evaluated by the Model of End-Stage Liver Disease (MELD) score at the same time as the laboratory test results were recorded on the medical charts (30).

The following laboratory variables were measured: hemoglobin, serum albumin, lymphocyte count, platelet count, international normalized ratio (INR), prothrombin activity, total bilirubin (TB), creatinine, alanine aminotransferase $(A L T)$, aspartate aminotransferase (AST), alkaline phosphatase (ALP) and gamma-glutamyl transferase (GGT). The hepaticfunction-related biochemical parameters AST, ALT, ALP and GGT are expressed as multiples of the upper limit of normal $(x \cup L N)$. The other laboratory variables are expressed as absolute values. TB, INR and creatinine were used for the MELD calculation. Only laboratory tests performed during hospitalization were considered in this study. All data were collected by the first author.

\section{Nutritional evaluation}

The nutritional condition was studied on the basis of the following nutritional evaluation methods: SGA, hematological (TLC) and biochemical (albumin) indicators $(2,17,21)$. Subjective and anthropometric data for SGA were collected and classified by a medical student under the supervision of a nutritionist and calculated using a questionnaire adapted from Detsky's proposal (21). The following aspects of the patient's clinical history were evaluated: weight change in the last six months (either increase or decrease), alterations in dietary intake, and presence of dyspeptic symptoms for more than two weeks and functional capacity with regard to the degree of stress caused by the disease. Although the literature shows 
great divergence on this matter (31-34), we considered all evaluated cirrhotic individuals to be presenting a moderate degree of stress. The parameters considered during physical examination included loss of subcutaneous fat, muscle loss, presence of malleolar edema, presacral edema and ascites.

The usual body weight element of the SGA is reported by the patient. In this study, the current weight was measured with the use of a portable mechanical scale (Mallory ${ }^{\circledR}$ mark, model 14578-01) with a maximum capacity of $120 \mathrm{~kg}$, a minimum of $1 \mathrm{~kg}$, and an accuracy of $0.05 \mathrm{~kg}$. From this weight, the water weight was subtracted per James's estimation (35), according to the intensity of the ascites and according to the peripheral edema, if present. Thus, the weight without the edema and ascites was obtained, and this measurement was considered the current weight (for the SGA).From the habitual weight reported by the patient and the current weight (the weight without edema and ascites), the percentage of weight loss was calculated.

The test for the loss of subcutaneous fat was performed with then on-dominant arm, which hung close to the patient's body and was examined by gripping the patient's arm flexure. Muscle loss was examined on the basis of the verification of the temporal and clavicular regions and forced adduction of the thumb and index finger. Based on the score of each parameter, patients were classified as adequately nourished, moderately malnourished or severely malnourished.

TLC was obtained by an automated method, the Sysmex XE-2100 Analyzer. The lysing reagent used for the differential leukocyte count was Stromatolyser-4DS, and the reagent used on diluted and lysed blood samples was Stromatolyser-4DL.

The albumin method employed here was an adaptation of the bromocresol purple binding method described by Carter (36) and Louderback et al (37). The sample collection, reagent dispersion, mixture, processing and result interpretation are automatically executed by the Dimension system.

On the basis of the laboratory results, different degrees of malnutrition were defined. In TLC, mild malnutrition was considered to correspond to values of 1,200 to 2,000 lymphocytes/mm3; moderate malnutrition, 800 to1,199 lymphocytes/ $\mathrm{mm} 3$; and severe malnutrition, lower than 800 lymphocytes/ $\mathrm{mm} 3$ (38). Patients with albumin higher than $3.5 \mathrm{~g} / \mathrm{dl}$ were considered normal; $3.0 / \mathrm{dL}$ to $3.5 \mathrm{~g} / \mathrm{dL}$, mildly malnourished; $2.4 \mathrm{~g} / \mathrm{dL}$ to $2.9 \mathrm{~g} / \mathrm{dL}$, moderately malnourished; and lower than $2.4 \mathrm{~g} / \mathrm{dL}$, severely malnourished (39).

Statistical analysis

Continuous variables were compared using Student's t test or the Mann-Whitney test, when appropriate. Categorical variables were compared using the chi-square test or Fisher's exact test when necessary. A P-value less than 0.05 was considered statistically significant. Bivariate analysis was used to identify variables associated with Child-Pugh class $C$ and with moderate to severe malnutrition in different nutritional classifications. Statistical analysis was performed using the Statistical Package for the Social Sciences, version 11.0 (SPSS Inc., Chicago, IL, USA).

\section{RESULTS}

Patient characteristics

From December 2011 to August 2012, 86 patients were evaluated for inclusion in the study because they presented cirrhosis. Six individuals were excluded for the following comorbidities: congestive heart failure $(n=1)$, chronic pancreatitis $(n=1)$ and HIV $(n=4)$. Eleven patients were also excluded for presenting more than one hospitalization, and 2 patients were excluded for hepatic encephalopathy of stage III-IV (figure 1).

\section{FIGURE 1}

Flow diagram of the potential candidates for participation in the study, reasons for exclusion, and subjects enrolled.

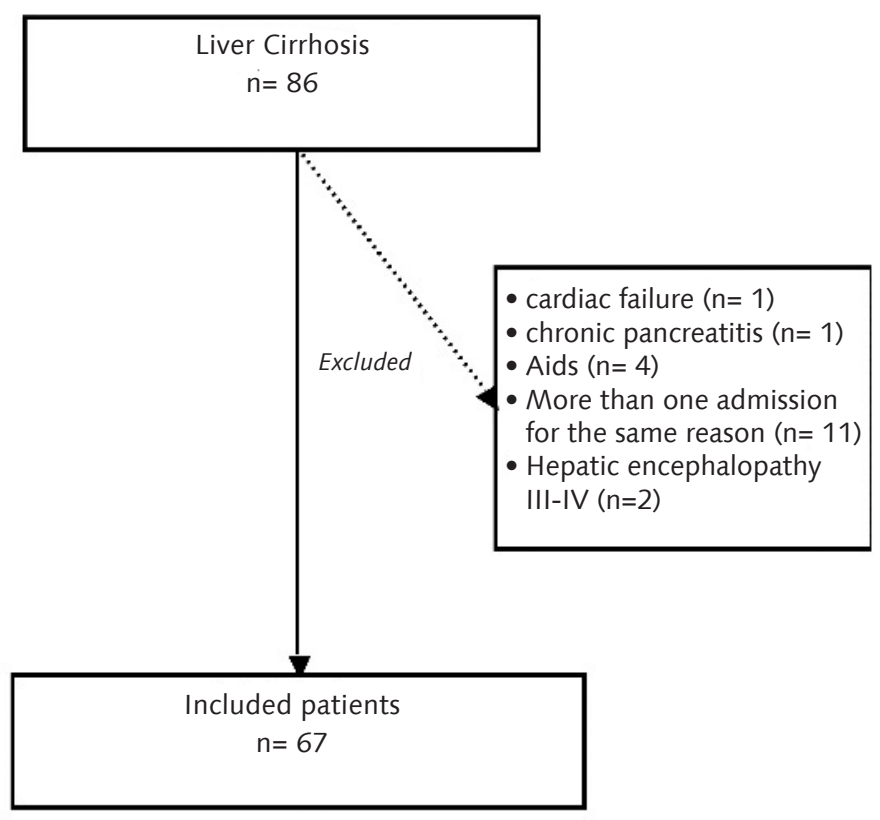


The characteristics of the 67 consecutive patients included in the study are summarized in table 1 . The mean age was $54.4 \pm 11.7$ years, $74.6 \%$ of the patients were men and $91.0 \%$ were Caucasian. Approximately $30 \%$ of the individuals were classified as Child-Pugh C. The mean MELD score was $14.5 \pm$ 6.5. More than half of the individuals presented ascites during hospitalization, $41.8 \%$ presented high digestive bleeding, 1/3 showed hepatic encephalopathy and only $3 \%$ were diagnosed with spontaneous bacterial peritonitis. With regard to the etiology of the cirrhosis, $43.3 \%$ presented alcoholism, 34.3\% hepatitis $C$ and $10.4 \%$ hepatitis $B$.

Regarding nutritional evaluation (table 2), $20.9 \%$ of the samples were classified as suffering from severe malnutrition by the SGA. Fifteen percent of the patients showed severe malnutrition, as indicated in the TLC, and $40.3 \%$ presented serious malnutrition, as indicated by the albumin concentration.

Evaluation of individuals included according to the Child-Pugh classification

When Child-Pugh $C$ individuals were compared to those classified as Child-Pugh class A/B, the former presented lower mean weight that was free from edema and ascites (64.4 \pm 17.4 versus $73.5 \pm 16.5 \mathrm{~kg}$; $\mathrm{P}=0.045)$. A greater proportion of Child-Pugh C individuals had lost more than $10 \%$ of body weight (61.9\% versus 34.8\%; $\mathrm{P}=0.038$ ), had been prescribed changes in diet ( $81 \%$ versus $50 \% ; P=0.017)$, had modified their diet for more than 30 days (75.0 versus $32.6 \% ; P=0.001$ ) and had fasted for more than 5 days (33.3\% versus $6.5 \%$; $P$ $=0.008$ ). The Child-Pugh $C$ patients also presented a higher frequency of physical capacity below normal for more than two weeks (76.2\% versus 50\%; $P=0.044)$, loss of subcutaneous fat $(71.4 \%$ versus $43.5 \% ; P=0.034)$ and edema of either the ankle $(76.2 \%$ versus $41.3 \%$; $P=0.008)$ or sacrum $(52.4 \%$ versus $17.4 \% ; P=0.003)$. With regard to the nutritional evaluation (table 3 ), a higher proportion of moderate or severe malnutrition was observed among Child-Pugh $C$ individuals according to the SGA $(P<0.001)$, albumin $(P=0.006)$ and TLC criteria $(P=0.024)$. The proportion of individuals with moderate to severe malnutrition did not differ between the Child-Pugh $C$ and Child-Pugh A-B groups ( $P=0.192)$.

\section{Evaluation of included individuals in accordance} with the nutritional classifications

When we compared the individuals who were classified as suffering from moderate to severe malnutrition by the SGA to the others (table 4 ), we observed that the former presented greater rates of ascites $(80.0 \%$ versus $35.1 \% ; P<0.001)$, hepatic encephalopathy $(43.3 \%$ versus $18.9 ; P=0.030)$ and

\section{TABLE 1}

Clinical characteristics and biochemical profile of 67 patients with cirrhosis.

Characteristics of the sample

\begin{tabular}{|c|c|}
\hline Age (years)* & $54.4 \pm 11.7(54)$ \\
\hline Male, n (\%) & $50(74.6)$ \\
\hline Caucasian, n (\%) & $61(91.0)$ \\
\hline MELD* & $14.5 \pm 6.5(13.0)$ \\
\hline \multicolumn{2}{|l|}{ Child-Pugh classification } \\
\hline - A, n (\%) & $12(17.9)$ \\
\hline$-\mathrm{B}, \mathrm{n}(\%)$ & $34(50.7)$ \\
\hline$-C_{1} n(\%)$ & $21(31.3)$ \\
\hline \multicolumn{2}{|l|}{ Cirrhosis decompensation on admission } \\
\hline - Ascites, n (\%) & $37(55.2)$ \\
\hline - Upper digestive bleeding, n (\%) & $28(41.8)$ \\
\hline - Hepatic encephalopathy, n (\%) & $20(29.9)$ \\
\hline - Spontaneous bacterial peritonitis, n (\%) & $2(3)$ \\
\hline \multicolumn{2}{|l|}{ Laboratory exams } \\
\hline - Hemoglobin (g/dL)* & $11.3 \pm 3.3(11.1)$ \\
\hline - Albumin $(g / d L)^{*}$ & $2.6 \pm 0.6(2.5)$ \\
\hline - Platelets $(/ \mathrm{mm} 3)^{*}$ & $108,238.8 \pm 78,292.0(92,000.0)$ \\
\hline - PA $(\%)^{*}$ & $54.4 \pm 17.4(53.6)$ \\
\hline - Total bilirubin $(\mathrm{mg} / \mathrm{dL}) *$ & $3.4 \pm 5.7(1.5)$ \\
\hline - Creatinine $(\mathrm{g} / \mathrm{dL})^{*}$ & $1.3 \pm 1.0(1.1)$ \\
\hline$-\operatorname{AST}(x \cup L N) *$ & $6.0 \pm 28.6(1.7)$ \\
\hline$-\operatorname{ALT}(x U L N) *$ & $1.7 \pm 3.8(0.8)$ \\
\hline$-\operatorname{ALP}(x U L N) *$ & $1.0 \pm 0.7(0.9)$ \\
\hline - GGT (xULN) * & $3.0 \pm 4.0(1.6)$ \\
\hline
\end{tabular}

$M E L D=$ Model of End-Stage Liver Disease; $\mathrm{PA}=$ prothrombin activity; $\mathrm{AST}=$ aspartate aminotransferase; $\mathrm{ALT}=$ alanine aminotransferase; $\mathrm{ALP}=$ alkaline phosphatase; GGT= gamma glutamyl transferase; $x \mathrm{XLN}=$ times the upper limit of normal; ${ }^{*}$ mean \pm standard deviation (median). 
Child-Pugh class C diagnosis (56.7\% versus $10.8 \%$; $P<0.001)$, as well as a greater median MELD score (14.5 versus 11.0; $\mathrm{P}=$ $0.001)$. With regard to the laboratory variables, we observed that the moderately and severely malnourished exhibited lower median prothrombin activity (50.1 versus 58.4\%; $\mathrm{P}=$ $0.017)$ and ALT (0.7 versus $1.0 \times U L N ; P=0.019)$ and lower mean albumin $(2.3 \pm 0.6$ versus $2.8 \pm 0.6 \mathrm{~g} / \mathrm{dL} ; \mathrm{P}=0.002)$. They also presented higher median bilirubin (2.1 versus 1.3 $\mathrm{mg} / \mathrm{dL} ; \mathrm{P}=0.021$ ).

When individuals classified by TLC as moderate to severe malnourished were compared to those with normal TLC (table $5)$, the former demonstrated a higher proportion of individuals with ascites (22\% versus $15 \% ; P=0.016)$, a greater proportion of patients classified as Child-Pugh C (14\% versus $7 \% ; P=0.024$ ) and higher mean MELD score (15 versus 11.5; $\mathrm{P}=0.002$ ). When we analyzed the laboratory variables, the moderately and severely malnourished (as classified by TLC) presented lower mean prothrombin activity $(49.3 \pm 13.3$ versus $58.7 \pm 19.4 \% ; P=0.026)$ and lower median ALT (0.7 versus 1.0 $x$ ULN; $P=0.015)$ and platelet count $(75,000.0$ versus 102,000 / $\mathrm{mm} 3 ; \mathrm{P}=0.0042)$. They also presented higher median bilirubin (2.5 versus $1.1 \mathrm{mg} / \mathrm{dL} ; \mathrm{P}=0.001$ ).

When we compared patients with moderate to severe malnutrition using the albumin classification to those classified as normal (table 6), the former group had a greater proportion of Child-Pugh C individuals (20.0\% versus $1.0 \% ; \mathrm{P}=0.006$ ), a greater proportion with ascites (32\% versus $5 \% ; P=0.006)$ and a greater median MELD score (14 versus $9.5 ; \mathrm{P}=0.001)$. With regard to the laboratory variables, the moderately and severely malnourished exhibited lower median prothrombin activity (50 versus $64.2 \% ; \mathrm{P}<0.001$ ) and platelet count (78,000 versus $111,000 / \mathrm{mm} 3 ; \mathrm{P}=0.024)$. Furthermore, they presented higher median bilirubin (1.9 versus $1.1 ; \mathrm{P}=0.017)$.

\section{DISCUSSION}

The mean age of cirrhotic individuals varies between $50.9 \pm 11.1$ and $55.1 \pm 11.4(1,2,13,14,40)$, with a male gender predominance $(66.7 \%$ to $75.3 \%)(1,2,31)$ and Caucasian

\section{TABLE 2}

Nutritional assessment of 67 patients with liver cirrhosis.

Subjective Global Assessment

Punctuation*

Nourished, n (\%)

Moderately malnourished, $\mathrm{n}(\%)$

Severely malnourished, n (\%)

Classification by total lymphocytes

Normal, n (\%)

Mild malnutrition, $\mathrm{n}(\%)$

Moderate malnutrition, $\mathrm{n}(\%)$

Severe malnutrition, $\mathrm{n}(\%)$

Classification by albumin

Normal, n (\%)

Mildly malnourished, $\mathrm{n}$ (\%)

Moderately malnourished, $\mathrm{n}(\%)$

Severely malnourished, n (\%)
$14.8 \pm 6.8(15)$

$37(55.2)$

$16(23.9)$

14 (20.9)

12 (17.9)

24 (35.8)

$21(31.3)$

10 (14.9)

$13(19.4)$

$22(32.8)$

$27(40.3)$

${ }^{*}$ Mean \pm standard deviation (median).

\section{TABLE 3}

Comparative analysis of nutritional evaluation of 67 patients with liver cirrhosis according to the Child-Pugh classification.

\begin{tabular}{|c|c|c|c|}
\hline & $\begin{array}{l}\text { Child-Pugh C } \\
n=21(31.3 \%)\end{array}$ & $\begin{array}{c}\text { Child-Pugh A-B } \\
n=46(68.7 \%)\end{array}$ & $\mathrm{p}$ \\
\hline Age $^{*}$ & $53.6 \pm 12.6$ & $54.7 \pm 11.3$ & $0.712 t$ \\
\hline Male, n (\%) & $16(76.2)$ & 34 (73.9) & $0.842 q$ \\
\hline Caucasian, n (\%) & $20(95.2)$ & $41(89.1)$ & $0.657 f$ \\
\hline \multicolumn{4}{|l|}{ Nutritional assessment } \\
\hline •SGA moderate/grave, n (\%) & $17(81.0)$ & $13(28.3)$ & $<0.001 \mathrm{q}$ \\
\hline -Albumin moderately/severely reduced (\%) & $20(95.2)$ & $29(63.0)$ & $0.006 q$ \\
\hline •TLC moderately/severely reduced (\%) & $14(66.7)$ & $17(37.0)$ & $0.024 q$ \\
\hline
\end{tabular}


predominance (41), similar to the present sample. Regarding prognostic classification, $18 \%$ of the studied individuals were classified as Child-Pugh A, 51\% as B and 31\% as C. This distribution is similar to that described by some authors: Child-Pugh A varies between $15.3 \%$ to $17.3 \%(1,2)$, and most of the patients are classified as Child-Pugh B (56.7\%) (1). The prevalence of Child-Pugh class C may vary widely, from $3.4 \%$ (12) to $48.7 \%$ (2), while similar frequencies to ours have also been reported (26\%-30\%) (1,32). While Gottschall et al. (14) reported that most patients (61.8\%) presented MELD scores between 10 and 19, Gunsar et al. (5) reported that patients' median MELD score was 15 (6-56), and both studies showed similar values to those in the present study $(14.5 \pm 6.5)$.

In the present study, individuals with moderate to severe malnutrition according to the SGA, albumin and TLC criteria were mainly classified as Child-Pugh C (67-95\%). Child-Pugh $C$ patients are malnourished by definition (42). Gunsar et al. (5) observed a 57\% rate of malnutrition among 222 cirrhotic individuals, whereas those who were seriously malnourished were more inclined to have moderate ascites and higher ChildPugh scores compared to those who were well nourished. Gunsar et al. (5) also noted a higher frequency of encephalopathy of stages I and II among the malnourished, as observed in the present study. Roongpisuthipong et al. (6) observed that the prevalence of protein-energy malnutrition increases as the severity of the illness increases and that protein-energy malnutrition is much more prevalent in Child-Pugh $C$ patients than in Child-Pugh A and B patients. In one study that evaluated a small proportion of Child-Pugh C outpatients (3\%), no nutritional classification was able to detect an association between malnutrition and severity of liver disease (Child-Pugh) (12). Hence, one could expect that when the majority of the individuals evaluated in a study are classified as Child-Pugh A or $\mathrm{B}$, low malnutrition rates will be found. Contrary to this expectation, although $69 \%$ of the hospitalized individuals in this study were classified as Child-Pugh A-B, severe malnutrition was detected in $15 \%$ to $48 \%$ of the cirrhotic individuals, depending on the method applied.

The signs associated with chronic liver disease, such as ascites, edema, altered immunocompetence, decreased protein synthesis and renal insufficiency may alter the objective criteria traditionally used in nutritional assessment. Thus, weight loss; anthropometric measurements; creatinine-height index; balanced nitrogenous excretion of 3-methyl-histidine; sensitivity tests of cutaneous lymphocyte count; and serum albumin, transferrin, prealbumin, and retinol-binding protein must be interpreted in the context of the nutritional status of these patients. However, most of these alterations reflect the progression of liver disease. Regardless, SGA seems to be the most suitable instrument for diagnosing malnutrition in cirrhotic patients (16). When50 cirrhotic outpatients were evaluated by Silva and Silveira (42), 88\% were classified as

\section{TABLE 4}

Comparative analysis of the laboratory and clinical characteristics of 67 patients with liver cirrhosis by the nutritional profile of Subjective Global Assessment.

\begin{tabular}{|c|c|c|c|}
\hline & $\begin{array}{l}\text { Moderately/severely malnourished } \\
\qquad \begin{array}{c}n=30 \\
44.8 \%\end{array}\end{array}$ & $\begin{array}{l}\text { Well nourished } \\
\qquad \begin{array}{l}\mathrm{n}=37 \\
55.2 \%\end{array}\end{array}$ & $P$ \\
\hline Age $^{*}$ & $55.0 \pm 12.1$ & $53.8 \pm 11.4$ & $0.673^{t}$ \\
\hline Male, n (\%) & $22(73.3)$ & $28(75.7)$ & $0.827^{q}$ \\
\hline Caucasian, n (\%) & $29(96.7)$ & $32(86.5)$ & $0.213^{f}$ \\
\hline Cirrhosis decompensation on admission, n (\%) & $27(90.0)$ & $29(78.4)$ & $0.321^{f}$ \\
\hline UDB, n (\%) & $11(36.7)$ & $17(45.9)$ & $0.444^{\mathrm{a}}$ \\
\hline $\mathrm{HE}, \mathrm{n}(\%)$ & $13(43.3)$ & $7(18.9)$ & $0.030^{q}$ \\
\hline Ascites, n (\%) & $24(80.0)$ & $13(35.1)$ & $<0.001^{9}$ \\
\hline SPB, n (\%) & $1(3.3)$ & $1(2.7)$ & $1.000^{f}$ \\
\hline Child-Pugh class C, n (\%) & $17(56.7)$ & $4(10.8)$ & $<0.001^{9}$ \\
\hline MELD\# & 14.5 & 11.0 & $0.001^{m}$ \\
\hline Platelets ${ }^{\#}$ & $86,000.0$ & $99,000.0$ & $0.820^{\mathrm{m}}$ \\
\hline Albumin* & $2.3 \pm 0.6$ & $2.8 \pm 0.6$ & $0.002^{t}$ \\
\hline $\mathrm{PA}^{\#}$ & 50.1 & 58.4 & $0.017^{m}$ \\
\hline $\mathrm{TB}^{\#}$ & 2.1 & 1.3 & $0.021^{\mathrm{m}}$ \\
\hline Creatinine $^{\#}$ & 1.1 & 1.0 & $0.259^{m}$ \\
\hline $\operatorname{ALT}(x \cup L N)^{\#}$ & 0.7 & 1.0 & $0.019^{m}$ \\
\hline AST $(x \cup L N)^{\#}$ & 1.6 & 1.8 & $0.367^{\mathrm{m}}$ \\
\hline $\operatorname{ALP}(x \cup L N)^{\#}$ & 0.9 & 0.8 & $0.188^{m}$ \\
\hline GGT $(x U L N)^{\#}$ & 1.9 & 1.6 & $0.537^{m}$ \\
\hline
\end{tabular}

$\mathrm{UDB}=$ upper digestive bleeding; $\mathrm{H}=$ hepatic encephalopathy; $\mathrm{SPB}=$ spontaneous bacterial peritonitis; $\mathrm{PA}=$ prothrombin activity; $\mathrm{TB}=$ total bilirubin;

$\mathrm{ALT}=$ alanine aminotransferase; $\mathrm{AST}=$ aspartate aminotransferase; $\mathrm{ALP}=$ alkaline phosphatase; $\mathrm{GGT}=$ gamma glutamyl transferase;

$\mathrm{xULN}=$ times the upper limit of normal; ${ }^{*}$ mean \pm standard deviation; \#median; $\mathrm{t}=$ Student's $\mathrm{t}$ test; $\mathrm{m}=$ Mann-Whitney test; $\mathrm{q}=\mathrm{chi}-\mathrm{square}$ test; $\mathrm{f}=\mathrm{Fisher}$ 's exact test. 
Child-Pugh $\mathrm{A}$ and $12 \%$ were Child-Pugh $\mathrm{B}$, with a prevalence of malnutrition of up to $63 \%$ according to handgrip strength and $28 \%$ according to SGA, demonstrating a high prevalence of malnutrition in cirrhotic outpatients and a large discrepancy between nutritional evaluation tools. Handgrip strength, but not SGA, predicted a poorer clinical outcome in patients with cirrhosis because major complications occurred in $65.5 \%$ of malnourished patients versus $11.8 \%$ of well-nourished ones $(\mathrm{P}<0.05)$.

However, some studies have demonstrated that the SGA has low sensitivity for the diagnosis of malnutrition. Gottschall et al. (14) evaluated 34 cirrhotic patients, $21 \%$ of whom were classified as Child-Pugh C. The prevalence of malnutrition was $35 \%$ by the SGA method, which was much higher than the prevalence estimated by other methods applied in their study, such as triceps skinfold (18\%) and upper arm circumference (6\%). Figueiredo et al. (40) assessed 79 cirrhotic patients, 72\% of whom were classified as Child-Pugh Thirty-two percent were malnourished according to SGA, 30\% were malnourished according to a traditional model, and $60 \%$ were malnourished according to the multicompartmental model. Once again, SGA misclassified malnutrition in two-thirds of the patients, mainly those with better liver function. It is conceivable that this finding occurred because the SGA does not classify mild malnutrition. Patients with a mild stage of malnutrition are classified as eutrophic, which may represent a mistake (43). In the present study, SGA classified $50 \%$ of the evaluated in- dividuals as well-nourished, while other methods considered 8-30\% of the patients to be eutrophic. It is recommended that the SGA be carried out within three days after hospitalization so that possible problems related to hospitalization and intrahospital malnutrition can be prevented (21). Hence, all patients in this study were evaluated within three days of admission.

Moderate to severe malnutrition was diagnosed by albumin classification in $73.1 \%$ of the studied patients. Decrease of serum albumin levels in patients with liver cirrhosis usually reflects liver synthesis disfunction and also is associated with malnutrition, due to food intake restriction and to the worsening metabolism of nutrients (44). Total lymphocytes count values were compatible with the diagnosis of moderate to severe malnutrition in $46.2 \%$ of the assessed patients. However, it is well known that the TLC evaluates immune competence and can be influenced by additional factors other than nutritional status, such as hiperesplenism and infections (45). These variables were not evaluated in the present work and are usually more frequent in advanced liver disease. The presence of hypersplenism could have contributed to the greater frequency of diagnosis of moderate to severe malnutrition by the TLC method among Child-Pugh C patients. Despite the ambiguity of biochemical markers, they have been widely used in the nutritional assessment of patients with liver cirrhosis $(1,3,4,22-26)$.

In 48 hospitalized patients with chronic liver disease, Pinedo et al. (46) found a positive linear correlation between

\section{TABLE 5}

Comparative analysis of the laboratory and clinical characteristics of 67 patients with liver cirrhosis by the nutritional profile by the classification of total lymphocyte.

\begin{tabular}{|c|c|c|c|}
\hline & $\begin{array}{l}\text { Moderate/Severe malnutrition } \\
\qquad n=31\end{array}$ & $\begin{array}{l}\text { Normal } \\
n=36\end{array}$ & $\mathrm{P}$ \\
\hline Age $^{*}$ & $56.0 \pm 13.1$ & $52.9 \pm 10.2$ & $0.279^{t}$ \\
\hline Male, n (\%) & $24(77.4)$ & $26(72.2)$ & $0.626^{q}$ \\
\hline Caucasian, n (\%) & $30(96.8)$ & $31(86.1)$ & $0.205^{f}$ \\
\hline Cirrhosis decompensation in admission, $\mathrm{n}(\%)$ & $29(93.5)$ & $27(75.0)$ & $0.041^{9}$ \\
\hline UDB, n (\%) & $12(38.7)$ & $16(44.4)$ & $0.635^{q}$ \\
\hline$H E, n(\%)$ & $10(32.3)$ & $10(27.8)$ & 0.6899 \\
\hline Ascites, n (\%) & $22(71.0)$ & $15(41.7)$ & $0.016^{9}$ \\
\hline SBP, n (\%) & $2(6.5)$ & $0(0.0)$ & $0.210^{f}$ \\
\hline Child-Pugh class C, n (\%) & $14(45.2)$ & $7(19.4)$ & $0.024^{9}$ \\
\hline MELD\# & 15.0 & 11.5 & $0.002^{\mathrm{m}}$ \\
\hline Platelets\# & $75,000.0$ & $102,000.0$ & $0.042^{\mathrm{m}}$ \\
\hline Albumin* & $2.5 \pm 0.6$ & $2.7 \pm 0.6$ & $0.099^{t}$ \\
\hline $\mathrm{PA}^{\#}$ & $49.3 \pm 13.3$ & $58.7 \pm 19.4$ & $0.026^{t}$ \\
\hline $\mathrm{BT}^{\#}$ & 2.5 & 1.1 & $0.001^{m}$ \\
\hline Creatinine $\#$ & 1.1 & 1.0 & $0.082^{\mathrm{m}}$ \\
\hline $\operatorname{ALT}(x \cup L N)^{\#}$ & 0.7 & 1.0 & $0.016^{m}$ \\
\hline AST $(x \cup L N)^{\#}$ & 1.5 & 1.8 & $0.372^{m}$ \\
\hline ALP $(x \cup L N)^{\#}$ & 0.8 & 0.9 & $0.534^{\mathrm{m}}$ \\
\hline GGT $(x \cup L N)^{\#}$ & 1.6 & 1.8 & $0.474^{m}$ \\
\hline
\end{tabular}

$\mathrm{UDB}=$ Upper digestive bleeding; $\mathrm{HE}=$ Hepatic encephalopathy; $\mathrm{SBP}=$ Spontaneous bacterial peritonitis; $\mathrm{PA}=\mathrm{Prothrombin}$ activity; $\mathrm{BT}=\mathrm{Total}$ bilirubin;

$\mathrm{ALT}=$ Alanine aminotransferase; $\mathrm{AST}=$ Aspartate aminotransferase; $\mathrm{ALP}=$ alkaline phosphatase; GGT= Gamma glutamyl transferase;

$x \mathrm{ULN}=$ Times the upper limit of Normal; ${ }^{*}$ Mean \pm standard deviation; \#Median; $t=$ Student's $t$ test; $m=$ Mann-Whitney; $q=$ Chi-square test; $f=$ Fisher's exact. 
malnutrition (evaluated by the protein-energy malnutrition index, in which one of the indicators was albumin and another TLC) and hepatic dysfunction, classified by the clinical and laboratory combined index proposed by Orrego et al. (47) Carvalho and Parise 1) analyzed the nutritional diagnosis of 300 cirrhotic patients with the protein-energy malnutrition score proposed by Mendenhall et al. (23), two components of which are albumin and lymphocyte percentage. The prevalence of moderate or severe protein-calorie malnutrition was higher in patients classified as Child-Pugh $C$ than in patients classified as Child-Pugh A (21\% versus 58\%). Figueiredo et al. (40) observed that albumin and lymphocytes were significantly reduced in patients compared with controls. Kawabe et al. (48) used the Maastricht index (49) and the Nutritional Risk index (50) for nutritional evaluation of 68 patients with cirrhosis, and both indexes use albumin and TLC. Serum albumin was significantly higher in patients with milder malnutrition than in those with more severe malnutrition, as assessed by the Maastricht index (no versus mild, $\mathrm{P}=0.0001$; mild versus moderate, $\mathrm{P}<0.0001$; moderate versus severe, $\mathrm{P}<$ $0.0001)$. Blood lymphocyte count was significantly higher in the patients with milder malnutrition than in those with more severe malnutrition, as assessed by the Maastricht index (no versus mild, $\mathrm{P}=0.0009$; mild versus moderate, $\mathrm{P}<0.0001$ ). Therefore, because of the difficulty of assessing each of the anthropometric and biochemical parameters separately, some methods have been used for protein-energy malnutrition classification, such as that proposed by Jeejeebhoy et al (51).
Only one anthropometric data point is insufficient to diagnose malnutrition; at least three are required (51).

It is important to note that the SGA in a subjective tool that is prone to the observer's interpretation; therefore, its diagnostic accuracy depends on the experience of each observer $(12,13)$. In this study, all data were collected and analyzed by the same person, so the bias from dubious interpretations was diminished. Each method alone may have its limitations, but based on the literature, three analyses or more can combine to produce a good nutritional characterization of a sample of patients with cirrhosis (51).

The proportion of cirrhotic individuals classified as moderate/severe malnourished varies substantially among different methods. Moderate and severe malnutrition is related to worsening of liver function tests. All methods employed in this study were correlated with Child-Pugh class $C$, demonstrating their effectiveness in diagnosing moderate to severe malnutrition in the cirrhotic patient. Thus, because of the high prevalence of malnutrition among cirrhotic individuals, nutritional evaluation is fundamentally important in this group, and as seen in this study, it can be performed by simple methods that are applicable to a hospital and out-patient routine in order to enable early intervention and prevention of complications.

\section{RESUMEN}

Contexto y objetivo: la desnutrición proteico-calórica es reportada en 25 a $100 \%$ de los pacientes con cirrosis. El objetivo de este estudio fue evaluar el estado nutricional de

\section{TABLE 6}

Comparative analysis of the laboratory and clinic characteristics of 67 patients with liver cirrhosis by the nutritional profile by the classification of albumin.

\begin{tabular}{|c|c|c|c|}
\hline & $\begin{array}{l}\text { Moderately/severely malnourished } \\
\qquad \mathrm{n}=49\end{array}$ & $\begin{array}{l}\text { Normal } \\
\mathrm{n}=18\end{array}$ & $P$ \\
\hline $\mathrm{Age}^{*}$ & $53.7 \pm 12.0$ & $56.2 \pm 10.8$ & $0.432^{t}$ \\
\hline Male, n (\%) & $37(75.0)$ & $13(72.2)$ & $0.762^{f}$ \\
\hline Caucasian, n (\%) & $45(91.8)$ & $16(88.9)$ & $0.656^{f}$ \\
\hline Cirrhosis decompensation on admission, $\mathrm{n}(\%)$ & $45(91.8)$ & $11(61.1)$ & $0.006^{f}$ \\
\hline UDB, n (\%) & $21(42.9)$ & $7(38.9)$ & $0.770^{q}$ \\
\hline $\mathrm{HE}, \mathrm{n}(\%)$ & $17(34.7)$ & $3(16.7)$ & $0.153^{q}$ \\
\hline Ascites, n (\%) & $32(65.3)$ & $5(27.8)$ & $0.006^{q}$ \\
\hline SBP, n (\%) & $2(4.1)$ & $0(0.0)$ & $1.000^{f}$ \\
\hline Child-Pugh class C, n (\%) & $20(40.8)$ & $1(5.6)$ & $0.006^{q}$ \\
\hline MELD $\#$ & 14.0 & 9.5 & $0.001^{\mathrm{m}}$ \\
\hline Platelets" & $78,000.0$ & $111,000.0$ & $0.024^{\mathrm{m}}$ \\
\hline $\mathrm{PA}^{\#}$ & 50.0 & 64.2 & $<0.001^{m}$ \\
\hline $\mathrm{TB}^{\#}$ & 1.9 & 1.1 & $0.017^{m}$ \\
\hline Creatinine $^{\#}$ & 1.0 & 1.1 & $0.903^{m}$ \\
\hline ALT $(x \cup L N)^{\#}$ & 0.8 & 1.0 & $0.329^{m}$ \\
\hline AST $(x \cup L N)^{\#}$ & 1.8 & 1.5 & $0.213^{m}$ \\
\hline $\operatorname{ALP}(x \cup L N)^{\#}$ & 0.9 & 0.8 & $0.854^{\mathrm{m}}$ \\
\hline GGT $(x \cup L N)^{\#}$ & 1.6 & 1.7 & $0.475^{\mathrm{m}}$ \\
\hline
\end{tabular}

$\mathrm{UDB}=$ upper digestive bleeding; $\mathrm{HE}=$ hepatic encephalopathy; $\mathrm{SBP}=$ spontaneous bacterial peritonitis; $\mathrm{PA}=$ prothrombin activity; $\mathrm{TB}=$ total bilirubin;

$\mathrm{ALT}=$ alanine aminotransferase; $\mathrm{AST}=$ aspartate aminotransferase; $\mathrm{ALP}=$ alkaline phosphatase; $\mathrm{GGT}=$ gamma glutamyl transferase;

$\mathrm{xULN}=$ times the upper limit of normal; ${ }^{*}$ mean \pm standard deviation; \#median; $\mathrm{t}=$ Student's $\mathrm{t}$ test; $\mathrm{m}=$ Mann-Whitney test; $\mathrm{q}=\mathrm{chi}$-square test; $\mathrm{f}=\mathrm{Fisher}$ 's exact test. 
los pacientes cirróticos e identificar las variables clínicas y de laboratorio asociadas a la desnutrición moderada a severa y correlacionarlas con los factores de pronósticos de la cirrosis (clasificación de Child-Pugh). Diseño y montaje: Este es un estudio transversal que evaluó pacientes cirróticos ingresados en el Hospital Universitario de diciembre 2011 a agosto 2012. Métodos: El estado nutricional se consiguió mediante la Evaluación Subjetiva Global (ESG), recuento total de linfocitos (RTL) y albúmina sérica. Un análisis bivariado se utilizó para identificar las variables asociadas con el Child $C$ y con la desnutrición Moderada-severa en diferentes clasificaciones nutricionales. Resultados: 67 pacientes fueron incluidos con una edad media de 54,4 \pm 11,7 años, 74,6 \% hombres. La media del registro MELD fue de $14,5 \pm 6,5$ y casi $30 \%$ de los individuos eran Child C. En cuanto al estado nutricional, el 20,9\% tenían desnutrición severa por ESG, 14,9\% por RTL, y el 40,3 \% por albúmina. Para todos los métodos, la malnutrición moderada severa se correlacionó con Child C. La tasa de malnutrición moderada a grave detectada en la población por ESG fue más baja que la demostrada por los métodos de laboratorio. Sin embargo, el ESG indica una mayor proporción de pacientes Child C y con desnutrición moderada a severa. Conclusiones: Dada la alta prevalencia de desnutrición y su correlación con la gravedad de la cirrosis, la evaluación nutricional de los pacientes con cirrosis hepática es un paso esencial que se puede lograr a través de métodos simples y de rutina del hospital.

Palabras clave: Cirrosis, linfocitos, desnutrición, evaluación nutricional, albúmina sérica.

\section{REFERENCES}

1. Carvalho L, Parise ER. Evaluation of nutritional status of nonhospitalized patients with liver cirrhosis. Arq Gastroenterol. 2006;43:269-74.

2. Maio R, Dichi JB, Burini RC. [Sensibility of anthropometriclaboratory markers of protein-energy malnutrition in cirrhotic patients]. Arq Gastroenterol. 2004;41:93-9.

3. DiCecco SR, Wieners EJ, Wiesner RH, Southorn PA, Plevak $D J$, Krom RA. Assessment of nutritional status of patients with end-stage liver disease undergoing liver transplantation. Mayo Clin Proc. 1989;64:95-102.

4. Guglielmi FW, Panella C, Buda A, Budillon G, Caregaro $L$, Clerici $C$, Conte D, et al. Nutritional state and energy balance in cirrhotic patients with or without hypermetabolism. Multicentre prospective study by the 'Nutritional Problems in Gastroenterology' Section of the Italian Society of Gastroenterology (SIGE). Dig Liver Dis. 2005;37:681-8.

5. Gunsar F, Raimondo ML, Jones S, Terreni N, Wong C, Patch $D$, Sabin $C$, et al. Nutritional status and prognosis in cirrhotic patients. Aliment Pharmacol Ther 2006;24:563-72.

6. Roongpisuthipong C, Sobhonslidsuk A, Nantiruj K, Songchitsomboon $S$. Nutritional assessment in various stages of liver cirrhosis. Nutrition 2001;17:761-5.

7. Qin H, Li H, Xing $M, W u C, L i G$, Song J. Nutritional support treatment for severe chronic hepatitis and posthepatitic cirrhosis. J Huazhong Univ Sci Technolog Med Sci. 2006;26:217-20.

8. Cabre E, Gonzalez-Huix F, Abad-Lacruz A, Esteve M, Acero D, Fernandez-Banares $F$, Xiol $X$, et al. Effect of total enteral nutrition on the short-term outcome of severely malnourished cirrhotics. A randomized controlled trial. Gastroenterology 1990;98:715-20.

9. Selberg O, Bottcher J, Tusch G, Pichlmayr R, Henkel E, Muller MJ. Identification of high-and low-risk patients before liver transplantation: a prospective cohort study of nutritional and metabolic parameters in 150 patients. Hepatology 1997;25:652-7.

10. Ritter L, Gazzola J. [Nutritional evaluation of the cirrhotic patient: an objective, subjective or multicompartmental approach?]. Arq Gastroenterol. 2006;43:66-70.

11. Kalaitzakis $E$, Simren $M$, Olsson $R$, Henfridsson $P$, Hugosson I, Bengtsson M, Bjornsson E. Gastrointestinal symptoms in patients with liver cirrhosis: associations with nutritional status and health-related quality of life. Scand J Gastroenterol. 2006;41:1464-72.

12. Nunes FF, SA; Bertolini, CM; Rabito, El; Gottschall, CBA. [Nutritional evaluation of cirrhotic patients: comparison between several methods]. Scientia Medica 2012;22:6.

13. Fernandes SA, Bassani L, Nunes FF, Aydos ME, Alves AV, Marroni CA. Nutritional assessment in patients with cirrhosis. Arq Gastroenterol. 2012;49:19-27.

14. Gottschall CB, Alvares-da-Silva MR, Camargo AC, Burtett $R M$, da Silveira TR. [Nutritional assessment in patients with cirrhosis: the use of indirect calorimetry]. Arq Gastroenterol. 2004;41:220-4.

15. Bragagnolo R, Caporossi FS, Dock-Nascimento DB, de Aguilar-Nascimento JE. [Adductor pollicis muscle thickness: a fast and reliable method for nutritional assessment in surgical patients]. Rev Col Bras Cir. 2009;36:371-6.

16. Barbosa-Silva MC, de Barros AJ. [Subjective global assessment: Part 2. Review of its adaptations and utilization in different clinical specialties]. Arq Gastroenterol. 2002;39:248-52.

17. Detsky AS, McLaughlin JR, Baker JP, Johnston N, Whittaker $S$, Mendelson RA, Jeejeebhoy KN. What is subjective global assessment of nutritional status? JPEN J Parenter Enteral Nutr. 1987;11:8-13.

18. Pikul J, Sharpe MD, Lowndes R, Ghent CN. Degree of preoperative malnutrition is predictive of postoperative morbidity and mortality in liver transplant recipients. Transplantation 1994;57:469-2.

19. Plauth M, Cabre E, Riggio O, Assis-Camilo M, Pirlich M, Kondrup J, Ferenci $P$, et al. ESPEN Guidelines on Enteral Nutrition: Liver disease. Clin Nutr. 2006;25:285-4.

20. Calamita Z, Burini RC. [Immunologic changes in alcoholic liver cirrhosis]. Arq Gastroenterol. 1995;32:79-84.

21. Coppini $L Z$, Waitzberg DL, Ferrini MT, da Silva ML, GamaRodrigues J, Ciosak SL. [Comparison of the subjective global nutrition assessment $x$ objective nutrition evaluation]. Rev Assoc Med Bras. 1995;41:6-10.

22. Caregaro L, Alberino F, Amodio P, Merkel C, Bolognesi $M$, Angeli $P$, Gatta A. Malnutrition in alcoholic and virusrelated cirrhosis. Am J Clin Nutr. 1996;63:602-9.

23. Mendenhall CL, Tosch T, Weesner RE, Garcia-Pont P, Goldberg SJ, Kiernan T, Seeff LB, et al. VA cooperative study on alcoholic hepatitis. II: Prognostic significance of proteincalorie malnutrition. Am J Clin Nutr. 1986;43:213-8.

24. Vieira PM, De-Souza DA, Oliveira LC. Nutritional assessment in hepatic cirrhosis; clinical, anthropometric, biochemical and hematological parameters. Nutr Hosp. 2013;28:1615-21.

25. Kim HK, Oh HJ, Nam SW, Choi JY, Cho SH, Yoon SK, Han $J Y$, et al. [Clinical and biochemical parameters of nutrition to predict hepatic encephalopathy in cirrhotic patients]. Korean J Gastroenterol. 2006;47:44-51.

26. Guo HM, Zhou L, Ma WC, Zhu YT, Wang Y, Wang J, Sun $X L$, et al. [Prevalence of nutritional risk among in-patients with liver diseases in Beijing, China]. Zhonghua Gan Zang 
Bing Za Zhi 2013;21:734-8.

27. Venegas Tresierra LF, Holguin Marin R, Yoza Yoshidaira $M$, Mormontoy Lauret $W$, Jara Cubas T, Polo Ramirez C, Vega Caico I. [Evaluation and nutritional therapy in cirrhotic patients of the "Edgardo Rebagliati Martins" hospital]. Rev Gastroenterol Peru 2002;22:13-8.

28. Rehm J, Taylor B, Mohapatra S, Irving H, Baliunas D, Patra J, Roerecke M. Alcohol as a risk factor for liver cirrhosis: a systematic review and meta-analysis. Drug Alcohol Rev. 2010;29:437-5.

29. Pugh RN, Murray-Lyon IM, Dawson JL, Pietroni MC, Williams $R$. Transection of the oesophagus for bleeding oesophageal varices. Br J Surg. 1973;60:646-9.

30. Brown RS, Jr., Kumar KS, Russo MW, Kinkhabwala M, Rudow DL, Harren P, Lobritto S, et al. Model for end-stage liver disease and Child-Turcotte-Pugh score as predictors of pretransplantation disease severity, posttransplantation outcome, and resource utilization in United Network for Organ Sharing status 2A patients. Liver Transpl. 2002; 8:278-84.

31. Peng S, Plank LD, McCall JL, Gillanders LK, Mcllroy $K$, Gane EJ. Body composition, muscle function, and energy expenditure in patients with liver cirrhosis: a comprehensive study. Am J Clin Nutr. 2007;85:1257-66.

32. Muller MJ, Bottcher J, Selberg O, Weselmann S, Boker KH, Schwarze M, von zur Muhlen A, et al. Hypermetabolism in clinically stable patients with liver cirrhosis. Am J Clin Nutr. 1999;69:1194-1201.

33. Schneeweiss $B$, Graninger $W$, Ferenci P, Eichinger $S$, Grimm $G$, Schneider B, Laggner AN, et al. Energy metabolism in patients with acute and chronic liver disease. Hepatology 1990;11:387-93.

34. Dolz C, Raurich JM, Ibanez J, Obrador A, Marse P, Gaya J. Ascites increases the resting energy expenditure in liver cirrhosis. Gastroenterology 1991;100:738-44.

35. James $R$. Nutritional support in alcoholic liver disease: a review. J Human Nutr Dietetics 1989;2:315-23.

36. Carter $P$. Ultramicroestimation of human serum albumin: Binding of the cationic dye, 5,5-dibromo-o-cresolsulfonphthalein. Microchemical 1970;15:531-9.

37. Louderback A, Mealey E, Taylor N. A new dye-binding technic using bromcresol purple for determination of albumin in serum. Clin Chem. 1968;14:2.

38. Blackburn GL, Bistrian BR, Maini BS, Schlamm HT, Smith MF. Nutritional and metabolic assessment of the hospital- ized patient. JPEN J Parenter Enteral Nutr 1977;1:11-22.

39. Gonzalez Madrono A, Mancha A, Rodriguez FJ, de Ulibarri $\mathrm{JI}$, Culebras J. The use of biochemical and immunological parameters in nutritional screening and assessment. Nutr Hosp. 2011;26:594-601.

40. Figueiredo FA, Perez RM, Freitas MM, Kondo M. Comparison of three methods of nutritional assessment in liver cirrhosis: subjective global assessment, traditional nutritional parameters, and body composition analysis. J Gastroenterol. 2006;41:476-2.

41. Douds AC, Cox MA, Iqbal TH, Cooper BT. Ethnic differences in cirrhosis of the liver in a British city: alcoholic cirrhosis in South Asian men. Alcohol Alcohol 2003;38:148-50.

42. Alvares-da-Silva MR, Reverbel da Silveira T. Comparison between handgrip strength, subjective global assessment, and prognostic nutritional index in assessing malnutrition and predicting clinical outcome in cirrhotic outpatients. Nutrition 2005;21:113-7.

43. Fontoura C, Cruz D, Londero L, Vieira R. Avaliação nutricional de paciente critico. Rev Bras Ter Intensiva 2006;18:8.

44. Nompleggi DJ, Bonkovsky HL. Nutritional supplementation in chronic liver disease: an analytical review. Hepatology 1994;19:518-33.

45. Blackburn GL, Harvey KB. Nutritional assessment as a routine in clinical medicine. Postgrad Med. 1982;71:46-63.

46. Pinedo S, Solano D, de la Villa FM, Bilbao Goitia P. [Proteincalorie malnutrition and degree of hepatic failure in chronic hepatopathy]. Rev Esp Enferm Dig. 1993;84:381-5.

47. Orrego $H$, Israel Y, Blake JE, Medline A. Assessment of prognostic factors in alcoholic liver disease: toward a global quantitative expression of severity. Hepatology 1983;3:896-905.

48. Kawabe N, Hashimoto S, Harata M, Nitta Y, Murao M, Nakano $T$, Shimazaki $H$, et al. Assessment of nutritional status of patients with hepatitis $C$ virus-related liver cirrhosis. Hepatol Res. 2008;38:484-90.

49. de Jong PC, Wesdorp RI, Volovics A, Roufflart M, Greep JM, Soeters $P B$. The value of objective measurements to select patients who are malnourished. Clin Nutr. 1985;4:61-6.

50. Perioperative total parenteral nutrition in surgical patients. The Veterans Affairs Total Parenteral Nutrition Cooperative Study Group. N Engl J Med. 1991;325:525-32.

51. Jeejeebhoy KN, Detsky AS, Baker JP. Assessment of nutritional status. JPEN J Parenter Enteral Nutr. 1990; 14: 193S-6S. 